\author{
Jurnal E-Bis (Ekonomi-Bisnis) \\ Vol.5 No.1 (2021) pp. 228-248 \\ https://jurnal.politeknik-kebumen.ac.id/index.php/E-Bis \\ p-ISSN : 2580-2062 e-ISSN : 2622-3368
}

\title{
Pengaruh Pelayanan Prima (Service Excellence) Terhadap Kepuasan Nasabah Pada Unit Pengelola Kegiatan (UPK) Galuh Buana Panumbangan Ciamis
}

\author{
Jajang Saeful Zaman ${ }^{1 *}$, Imas Matsny Mardiah ${ }^{2}$ \\ ${ }^{1}$ Keuangan \& Perbankan, STIE Latifah Mubarokiyah, Indonesia \\ ${ }^{2}$ Manajemen, STIE Latifah Mubarokiyah, Indonesia \\ *Email: jajangsaefulzaman@gmail.com \\ Doi : https://doi.org/10.37339/jurnal e-bis.v5i1.512
}

\begin{tabular}{ll}
\hline & Diterbitkan oleh Politeknik Dharma Patria Kebumen \\
\hline $\begin{array}{l}\text { Info Artikel } \\
\text { Diterima : }\end{array}$ & ABSTRAK \\
2021-03-18 & $\begin{array}{l}\text { Penelitian ini bertujuan untuk mengetahui besarnya pengaruh pelayanan prima } \\
\text { terhadap kepuasan nasabahpada UPK Galuh Buana Panumbangan Ciamis.Penelitian } \\
\text { ini menggunakan metode deskriptif kuantitatif. Sampel penelitian ini adalah } 61\end{array}$ \\
Diperbaiki : & nasabah yang menjadi ketua kelompok SPKPpada UPK Galuh Buana Panumbangan \\
C21-06-08 & Ciamis pada tahun 2019. Pengumpulan data dilakukan dengan menggunakan \\
& kuesioner dan dokumentasi. Teknik analisis data adalah uji prasyarat analisis dengan \\
Disetujui : & uji normalitas dan uji linearitas, selanjutnya di analisis denganregresi linear sederhana. \\
Hasi-06-08 & Hasil penelitian mengidentifikasikan bahwa pelayanan prima memiliki hubungan yang \\
& sangat kuat yakni sebesar 0,845 dan pengaruh yang positif dengan dampak yang \\
& signifikan terhadap kepuasan nasabah pada taraf 5\%. Koefisien determinasi sebesar \\
& 0,714 artinya 71,4\% kepuasan nasabah dipengaruhi oleh pelayanan prima UPK Galuh \\
Buana Panumbangan Ciamis dan sisanya 28,6\% dipengaruhi oleh variabel dan faktor & lain diluar penelitian ini baik secara internal dan eksternal.
\end{tabular}

\section{Kata Kunci: Pelayanan Prima, Kepuasan Nasabah, UPK}

\begin{abstract}
This research aimed to know how big the influence of excellent services on customers' satisfaction at UPK Galuh Buana Panumbangan Ciamis. This research usesed descriptivequantitative method. The sample of this research was 61 customers' who became the head of the SPKP group at UPK Galuh Buana Panumbangan Ciamis in 2019. The data was collectedby using questionnaire and documentation. Data analysis technique is a prerequisite test of analysis with normality and linearity test, the next step is to analyze to simple linear regression. The results of the researchcarried out identified that excellent services had a very strong relationship of 0.845 and positive influence and significant impact on customers' satisfaction at the level 5\%. Coefficient of determination 0.714 means $71.4 \%$ the customers' satisfaction was influenced by excellent services of UPK Galuh Buana Panumbangan Ciamis and employee while the rest $28.6 \%$ was influenced by other variable which were not beingresearched in this research.
\end{abstract}

Keywords: write down 3-5 keywords related to the content of the paper Alamat Korespondensi $\quad: \quad$ Jl. Letnan Jenderal Suprapto No.73 Kebumen, Jawa Tengah, Indonesia 55431 


\section{PENDAHULUAN}

Peraturan Menteri Keuangan Republik Indonesia Nomor 12/PMK.05/2012 tentang Penyusunan dan Pelaksanaan Daftar Isian Pelaksanaan Anggaran Lanjutan Program/Kegiatan Nasional Pemberdayaan Masyarakat Mandiri Tahun Anggaran 2012 dengan Sumber Dana dari Sisa Anggaran Program/Kegiatan Nasional Pemberdayaan Masyarakat Mandiri Tahun Anggaran 2011, pada pasal 1 ayat 1 mengatakan bahwaProgram/Kegiatan Nasional Pemberdayaan Masyarakat (PNPM) Mandiri yang selanjutnya disebut PNPM Mandiri adalah Program Nasional dalam wujud kerangka kebijakan sebagai dasar dan acuan pelaksanaan program-program penanggulangan kemiskinan berbasis pemberdayaan masyarakat. Sedangkan pada ayat 2 disebutkan PNPM Mandiri Perdesaan adalah Program Nasional dalam wujud kerangka kebijakan sebagai dasar dan acuan pelaksanaan program-program penanggulangan kemiskinan berbasis pemberdayaan masyarakat di perdesaan.Kebijakan PNPM Mandiri Perdesaan merupakan kelanjutan dari Program Pengembangan Kecamatan (PPK). Untuk mengelola kegiatan/pembangunan antar wilayah desa maka dibentuklah Badan Kerjasama Antar Desa yang disingkat BKAD. Untuk menjalankan fungsi perlindungan dan pelestarian serta pengembangan hasil-hasil kegiatan PPK/PNPM Mandiri Perdesaan, maka BKAD memberikan mandat kepada Unit Pengelola Kegiatan (UPK) sebagai pelaksana teknis operasional kegiatan BKAD.

UPK merupakan unit yang membawahi kegiatan masyarakat desa di kecamatan dan membantu Badan Kerjasama antar Daerah (BKAD) dalam menyelenggarakan pertemuan di Kecamatan.Dalam memberikan kualitas kinerja yang baik dalam melayani masyarakat UPK memperhatikan Standar Pelayanan Publik sebagaimana telah ditetapkan pemerintah dalam UU 25 Tahun 2009 untuk menilai efektifitas pelayanan dan mengukur kepuasan. Penilaian dilakukan sebagai sarana peningkatan layanan untuk meningkatkan kualitas, kejelasan, kecepatan dan skalabilitas(Kriswahyu, 2009).Pelayanan yang baik adalah pelayanan yang terbaik untuk memenuhi harapan dan kebutuhan pelanggan. Pelayanan yang baik adalah yang memenuhi standar kualitas yang ditetapkan (Rangkuty, 2017).

UPK Galuh Buana Panumbangan Ciamis adalah Lembaga pengelola kegiatan ekonomi pemberdayaan pasca PPK, PNPM, dan PNPM Mandiri Perdesaan, yang merupakan program pemerintah berkelanjutan untuk meningkatkan pertumbuhan ekonomi dan pemerataan pembangunan ekonomi yang berbasis desa atau perdesaan dengan mengutamakan sistem pemberdayaan seutuhnya.UPK Galuh Buana dalam menjalankan bidang usahanya sangat mengutamakan pelayanan prima terhadap nasabahnya seperti, bersikap sopan santun, ramah, menjalin komunikasi yang baik dengan nasabah, serta didukung dengan fasilitas yang ada di kantor. Pada UPK Galuh Buana sampai dengan tahun 2019 terdapat beberapa bidang usaha yaitu Kredit Simpan Pinjam Kelompok Perempuan (SPKP), Unit Perdagangan Kredit, dan Unit Jasa.

Simpan Pinjam Kelompok Perempuan (SPKP) pada UPK Galuh Buana Panumbangan merupakan jasa dalam memberikan pinjaman kepada masyarakat dengan cara membentuk kelompok, serta ketua setiap kelompok. SPKP ini dibuat oleh UPK Galuh Buana 
Panumbangan dengan harapan dapat mengurangi pengangguran dan digunakan membentuk usaha-usaha kecil sehingga meningkatkan kesejahteraan masyarakat khusus wilayah kecamatan Panumbangan. Selain itu masyarakat yang ekonominya bertaraf rendahpun bisa menjadi nasabah karena Program SPKP ini mempunyai bunga yang tidak terlalu besar.

Nasabah SPKP pada UPK Galuh Buana Panumbangan Ciamis berasal dari 14 desa yang ada dikecamatan Panumbangan yaitu Desa Medanglayang, Desa Panumbangan, Desa Tanjungmulya, Desa Sukakerta, Desa Golat, Desa Sindangherang, Desa Sindangmukti, Desa Jayagiri, Desa Banjaransana, Desa Payungsari, Desa Payungagung, Desa Sindangbarang dan Desa Buanamekar.Selain Program SPKP, UPK Galuh Buana juga memiliki Program Unit Perdagangan Kredit yang merupakan salah satu bidang usaha dalam menjual barang-barang dengan cara kredit atau kontan. Nasabah Unit Perdagangan Kredit di UPK ini tidak hanya masyarakat Kecamatan Panumbangan tetapi ada dari luar Kecamatan Panumbangan, biasanya apabila ada barang yang tidak tersedia di UPK Galuh Buana Panumbangan maka harus melakukan pemesanan terlebih dahulu.Unit Pengelola Kegiatan (UPK) Galuh Buana Panumbangan selain memiliki program SPKP dan Unit Perdagangan Kredit memiliki juga program baru yang dirintis pada tahun 2018 yaitu Unit jasa yang merupakan pelayanan jasa Sistem Administrasi Manunggal Satu Atap (SAMSAT). Dengan adanya program ini, Unit Pngelola Kegiatan (UPK) dapat melayani dan memudahkan masyarakat Kecamatan Panumbangan bahkan diluar Panumbangan dalam pengurusan dokumen atau pajak kendaraan.

UPK Galuh Buana Panumbangan perlu memperhatikan tentang Kepuasan Nasabah dengan berupaya terus memberikan Pelayanan yang Prima. Kepuasan pelanggan adalah kegembiraan atau rasa kecewa seseorang karena membandingkan produk yang ditemukan atau kinerja layanan (atau produk) berdasarkan harapan(Kotler \& Keller, 2016).

Fenomena yang terjadi jumlah kelompok yang di danai pada tahun 2017 sebanyak 191 kelompok dengan jumlah anggota sebanyak 2.094 orang. Kemudian pada tahun 2018 mengalami penurunan sebesar $8,9 \%$ yaitu 174 kelompok dengan jumlah anggota 1.787 orang. Begitupun pada tahun 2019 terjadi penurunan dari tahun sebelumnya sebesar 12,6\% yaitu 152 kelompok dengan anggota sebanyak 1.655 orang.Hal itu menunjukkan bahwaterindikasi adanya ketidakpuasan dari Nasabah UPK Galuh Buana Panumbangan.

Berdasarkan observasi, ketidakpuasan tersebut terjadi karena nasabah merasa kecewa dengan lambatnya pelayanan yang diberikan dalam memenuhi pesanan barang yang dipesan nasabah. Dengan menurunnya jumlah nasabah tersebut, berdampak pada menurunnya total pendapatan per tahunnya, yang semula pada tahun 2017 sebesar Rp. 1.727.971.308 menurun 1,6\% pada tahun 2018 yaitu menjadi Rp. 1.700.997.998. dan pada tahun 2019 terjadi penurunan sebesar $0,7 \%$ dari tahun sebelumnya dengan total pendapatan sebanyak Rp. 1.688.933.114.

Berdasarkan permasalahan yang dikemukakan di atas, maka peneliti tertarik mengambil judul "Pengaruh Pelayanan Prima (service excellence) Terhadap Kepuasan Nasabah Pada Unit Pengelola Kegiatan (UPK) Galuh Buana Panumbangan Ciamis".

\section{KAJIAN PUSTAKA}

\subsection{Pelayanan Prima (Service Excellence)(X)}


Pelayanan Prima (service excellence) adalah suatu pelayanan terbaik dalam memenuhi harapan dan kebutuhan nasabah. Dengan kata lain, pelayanan prima merupakan suatu pelayanan yang memenuhi standar kualitas yang sudah di tentukan (Rangkuty, 2017). Service Excellence merupakan derivasi Total Quality Management (TQM) dalam industri jasa yang berkomitmen untuk dapat meningkatkan kualitas layanan perusahaan maka perlu untuk mengintegrasikan dan memahami semua aktivitas dalam perusahaan bisnis ini harus terus bekerja setiap saat untuk meningkatkan penjualan. mereka akan mendapatkan pangsa pasar yang lebih besar(Antoni, 2018).Prinsip pelayanan yang baik sejalan dengan A6, yaitu: 1) Ability (Kemampuan), merupakan suatu pengetahuan dan keterampilan yang penting untuk mendukung proyek pelayanan yang baik. 2) Attitude (Sikap), adalah perilaku atau semangat yang harus membuat Anda merasa dihargai dalam hubungannya dengan pelanggan. Sikap yang menggambarkan perilaku atau gejala yang ditemukan pada seseorang saat dia menghadapi situasi tertentu atau berurusan dengan orang lain. Sikap bukanlah sesuatu yang ada sejak lahir, karena sifat sikap dalam diri seseorang dimungkinkan karena adanya interaksi seseorang dengan berbagai hal di lingkungannya. 3) Appearrance (penampilan) adalah keadaan seseorang, baik fisik maupun non fisik, mampu mengungkapkan dirinya dan jujur kepada pihak lain. 4) Attention (Penampilan), memperhatikan kebutuhan dan keinginan pelanggan dan memahami pikiran dan keberatan mereka. 5) Action (Tindakan), merupakan pekerjaan nyata yang harus dilakukan untuk memberikan pelayanan kepada pelanggan. Jika ada hubungan dengan penyedia layanan, itu adalah aktivitas atau aktivitas tertentu yang berusaha memberikan layanan yang bermanfaat atau efektif. 6) Akuntabilitas adalah sikap side-by-side terhadap pelanggan sebagai bentuk agresi untuk menghindari atau meminimalkan kehilangan pelanggan dengan atau tanpa kepuasan(Rangkuty, 2017). Tujuan dari Pelayanan Prima adalah memberikan layanan yang memenuhi dan memuaskan pelanggan sesuai dengan kebutuhan pelanggan(Rangkuty, 2017). Oleh karena itu, literatur sebelumnya menunjukkan bahwa Pelayanan Prima (Service Excellence) memiliki pengaruh yang positif dan signifikankan terhadap Kepuasan Nasabah (Sebayang, 2019).

\subsection{Kepuasan Nasabah (Y)}

Kepuasan nasabah merupakan hal penting yang diharapkan setiap bisnis untuk dapat memberikan yang terbaik kepada pelanggannya(Dwi Divayana \& Rahanatha, 2018). Kepuasan pelanggan adalah yang membuat seseorang merasa senang atau sedih, dari membandingkan suatu produk atau jasa (atau produk) dengan ekspektasi.(Kotler \& Keller, 2016). Sejalan dengan Kotler, bahwa Kepuasan pelanggan adalah tinjauan pasca-pembelian yang memenuhi alternatif atau melebihi harapan(Sunyoto, 2015). Kepuasan dilihat seseorang melalui perasaan senang atau sedih yang muncul setelah membandingkan sifat pekerjaan yang diberikan melalui jasa(Dwi Divayana \& Rahanatha, 2018). Ada beberapa metode yang dapat digunakan untuk mengukur kepuasan pelanggan, yaitu: 1) Sistem Keluhan dan Saran. Perusahaan want-toconsumer perlu menyediakan cara paling sukses bagi pelanggannya untuk menyampaikan pendapat, keberatan, opini, dan keluhan mereka. 2). Ghost/ Mystery Shopping. Salah satu metode untuk mendapatkan wawasan tentang kesejahteraan nasabah adalah dengan mempekerjakan beberapa pembeli misteri serta perusahaan kinerja dan pesaing. 3). Lost Customer Analysis. Perusahaan perlu menghubungi pelanggan yang telah berhenti menjual 
atau telah berganti pemasok, untuk memahami mengapa hal ini terjadi sehingga proyek perbaikan / perbaikan dapat dilaksanakan. 4) Survey Kepuasan Nasabah. Tentu saja, sebagian besar survei kepuasan nasabah menggunakan metode survei, baik melalui pos, telepon, email, atau pertanyaan langsung. Melalui survei, umpan balik pelanggan dan umpan balik dari pelanggan dapat diperoleh dengan cepat, menunjukkan bukti yang baik bahwa perusahaan memperhatikan mereka(Tjiptono, 2014).

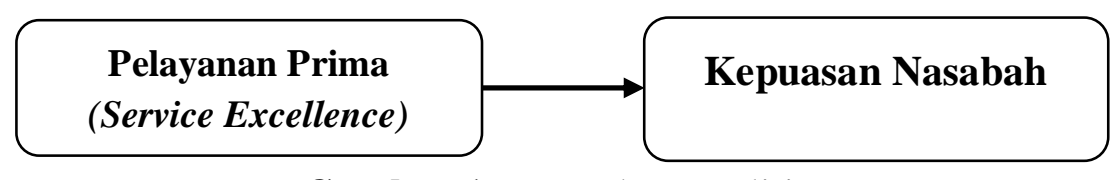

Gambar 1.Kerangka Penelitian

Sumber: Gambar diolah

\section{METODE}

Metode yang digunakan dalam penelitian ini yaitu metode deskriptif kuantitatif, karena selain menggambarkan juga dilakukan pengukuran untuk diambil suatu keputusan. Metode kuantitatif adalah metode penelitian berdasarkan filosofi positivisme, digunakan untuk meneliti populasi atau sampel tertentu, pengumpulan data menggunakan alat penelitian, analisis dan statistik kuantitatif, dan menguji hipotesis yang telah ditetapkan (Sugiyono, 2017). Sedangkan metode deskriptif adalah metode memeriksa sifat sekelompok orang, properti, kelompok budaya, sistem pemikiran, atau kelas peristiwa di zaman modern (Sugiyono, 2017).

Penelitian ini dilakukan untuk menguji hipotesis yang telah dilakukan dengan cara mencari besarnya pengaruh variabel bebas terhadap variabel terikat. Melalui metode kuantitatif dan analisis deskriptif ini diharapkan dapat diketahui sejauh mana pengaruh pelayanan prima terhadap kepuasan nasabah pada UPK Galuh Buana Panumbangan Ciamis.

\subsection{Populasi dan Sampel}

\section{Populasi Penelitian}

Populasi yang digunakan dalam penelitian ini adalah Nasabah yang menjadi ketua kelompok SPKPUPK Galuh Buana Panumbangan Ciamis tahun 2019 yang berjumlah 152 orang. Lebih jelasnya dapat di lihat pada tabel 1 berikut ini:

Tabel 1. Jumlah Kelompok di Danai dan Anggota UPK Galuh Buana Panumbangan

\begin{tabular}{lccc}
\hline \multicolumn{1}{c}{ Data } & $\mathbf{2 0 1 7}$ & $\mathbf{2 0 1 8}$ & $\mathbf{2 0 1 9}$ \\
\hline Jumlah Kelompok diDanai & 191 & 174 & 152 \\
Jumlah Anggota & 2.094 & 1.787 & 1.655 \\
\hline
\end{tabular}

Sumber: Data UPK Galuh Buana Panumbangan

\section{Sampel Penelitian}

Sugiyono (2017) mengemukakan bahwa: Sampel merupakan bagian dari jumlah dan karakteristik populasi. Jika populasinya sangat besar sehingga peneliti tidak dapat mempelajari semua aspek dari populasi tersebut, misalnya karena keterbatasan uang, tenaga dan waktu, 
maka peneliti dapat menggunakan model yang diturunkan dari populasi tersebut. Untuk alasan ini, sampel yang diambil dari populasi harus sangat mewakili.

Dalam penelitian ini, untuk penentuan besar sampel penulis menggunakan rumus Slovin. Dengan tingkat kepercayaan $90 \%$ dengan e $=10 \%$ adalah sebagai berikut:

Rumus:

$$
n=\frac{\mathrm{N}}{1+\mathrm{Nx}\left(\mathrm{e}^{2}\right)}
$$

(Sujarweni, 2015)

Keterangan :

$\mathrm{n}=$ jumlah sampel

$\mathrm{N}=$ jumlah populasi

$\mathrm{e}=$ tingkat kesalahan dalam memilih anggota sampel yang

ditolerir sebesar $10 \%$

Maka besaran sampel yang diambil dalam penelitian ini yaitu:

$$
\begin{aligned}
& n=\frac{\mathrm{N}}{1+\mathrm{Nx}\left(\mathrm{e}^{2}\right)} \\
& n=\frac{152}{1+152\left(0,1^{2}\right)}
\end{aligned}
$$

$\mathrm{n}=60.31$ dibulatkan jadi 61 orang.

Menurut Sugiyono (2017), Tekhnik sampling merupakan tekhnik pengambilan sampel. Untuk menentukan sampel digunakan beberapa metode pengambilan sampel. Dalam penelitian ini, peneliti menggunakan teknik Probability Sampling yaitu teknik pengambilan sampel yang memberikan tingkat keberhasilan untuk setiap segmen (anggota) populasi yang akan dipilih sebagai anggota sampel. Dengan memilih Simple Random sampling. Dikatakan simple (sederhana) karena sampel diacak dari populasi dengan tidak memperhatikan strata dalam populasi.

\subsection{Definisi Operasionalisasi Variabel Penelitian}

Definisi Operasionalisasi Variabel Sub bab ini memberikan penjelasan secara ringkas mengenai operasionalisasi dari variabel-variabel yang digunakan sebagai model penelitian ini. Definisi operasional variabel yang akan digunakan pada penelitian ini dapat dilihat pada Tabel 2 di bawah ini.

Tabel 2. Definisi Operasionalisasi Variabel

\begin{tabular}{llll} 
Variabel & Definisi Operasional & \multicolumn{1}{c}{ Indikator } & $\begin{array}{c}\text { Skala } \\
\text { Pengukuran }\end{array}$ \\
& Pelayanan Prima adalah & a. Ability (Kemampuan) & Likert \\
Pelayananan terbaik dalam & b. Attitude (Sikap) & \\
& memenuhi harapan dan & c. Appearrance &
\end{tabular}


@ Jajang Saeful Zaman ${ }^{1 *}$, Imas Matsny Mardiah²

\begin{tabular}{|c|c|c|c|c|}
\hline$(X)$ & $\begin{array}{c}\text { kebutuhan nasabah UPK } \\
\text { Galuh Buana } \\
\text { Panumbangan Ciamis }\end{array}$ & $\begin{array}{l}d . \\
e . \\
f .\end{array}$ & $\begin{array}{l}\text { (Penampilan) } \\
\text { Attention (Perhatian) } \\
\text { Action (Tindakan) } \\
\text { Acoountability } \\
\text { (Tanggung Jawab) }\end{array}$ & \\
\hline $\begin{array}{l}\text { Kepuasan Nasabah } \\
\text { (Y) }\end{array}$ & $\begin{array}{l}\text { Kepuasan Nasabah adalah } \\
\text { harapan atau perasaan } \\
\text { nasabah menggunakan } \\
\text { jasa UPK Galuh Buana } \\
\text { Panumbangan Ciamis. }\end{array}$ & $\begin{array}{l}\mathrm{a} \\
\mathrm{b} \\
\mathrm{c} \\
\mathrm{d} \\
\mathrm{e}\end{array}$ & $\begin{array}{l}\text { Loyal } \\
\text { Mengulang } \\
\text { kembali pembelian } \\
\text { produknya } \\
\text { Membeli lagi produk } \\
\text { lain } \\
\text { Memberikan promosi } \\
\text { gratis dari mulut ke } \\
\text { mulut }\end{array}$ & Likert \\
\hline
\end{tabular}

Sumber: Data diolah

\subsection{Metode Pengumpulan Data}

\section{Kuesioner}

Sugiyono (2017) meyatakan "Kuesioner merupakan teknik pengumpulan data yang dilakukan dengan cara memberikan seperangkat pertanyaan atau pertanyaan tertulis kepada responden untuk dijawab". Data yang diminta dari responden adalah hal-hal yang berkaitan dengan pelayanan prima dalam upaya meningkatkan kepuasan nasabah pada UPK Galuh Buana Panumbangan Ciamis. Pada penelitian ini, kuesioner dibagikan kepadanasabah yang menjadi ketua SPKP UPK Galuh Buana Panumbangan Ciamis.

Kuesioner penelitian disusun dengan cara mengajukan pertanyaan-pertanyaan yang disusun menurut indicator-indikator penelitian yang diperoleh dari pengembangan hasil kajian pustaka. Pengukuran kuesioner menggunakan skala data ordinal dan skala pengukurannya menggunakan skala likert. Sugiyono (2016) menjelaskan:Skala likert digunakan untuk mengukur sikap, pendapat, dan persepsi seseorang atau sekelompok orang tentang fenomena sosial. Jawaban setiap item instrument yang menggunakan Skala Likert mempunyai gradasi dari sangat positif sampai sangat negatif, yang antara lain:

1. Sangat setuju

2. Setuju

3. Kurang setuju

4. Tidak setuju

5. Sangat tidak setuju

Untuk keperluan analisis kuantitatif, maka jawaban itu dapat diberi skor sebagai berikut:

1. Sangat setuju diberi skor 5

2. Setuju diberi skor 4

3. Kurang setuju diberi skor 3

4. Tidak setuju diberi skor 2

5. Sangat tidak setuju diberi skor 1 


\section{Dokumentasi}

Teknik Dokumentasi dalam penelitian ini dimaksudkan untuk memperoleh data yang tersedia dalam bentuk arsip atau buku yang mendukung penelitian. Pengumpulan data dengan dokumentasi yang diperoleh dari hasil laporan dan keterangan tertulis, tergambar, maupun tercetak yang berupa data organisasi, data jumlah kelompok SPKP, SOP, Standar pelayanan yang diterapkan.

\subsection{Uji Validitas dan Reliabilitas}

\section{Uji Validitas}

Uji validitas digunakan untuk menguji apakah suatu pertanyaan layak digunakan sebagai alat penelitian. Alat pengumpul data dikatakan sevalid mungkin sehingga dapat menampilkan informasi dan atau informasi dari suatu variabel yang relevan dengan penelitian dan mampu mengukur kebutuhan penelitian. Uji validitas digunakan dengan membandingkan nilai $r_{\text {hitung }}$ dengan nilai $r_{\text {tabel }}$. Uji validitas item atau butir dapat dilakukan dengan menggunakan software SPSS.

Teknik pengujiannya menggunakan korelasi pearson product moment dengan rumus menurut Sujarweni (2015)sebagai berikut:

$$
r x y=\frac{n \sum x y-\left(\sum x\right)\left(\sum y\right)}{\sqrt{\left\{n\left(\sum x^{2}\right)-\left(\sum x\right)^{2}\right\}\left\{n\left(\sum y^{2}\right)-\left(\sum y\right)^{2}\right\}}}
$$

Keterangan:

rxy $=$ koefisien korelasi antara variabel $\mathrm{x}$ dan $\mathrm{y}$

$\sum x y=$ junlah perkalian antara variabel $\mathrm{x}$ dan $\mathrm{y}$

$\sum x^{2}=$ jumlah dari nilai kuadrat nilai $\mathrm{X}$

$\sum y^{2}=$ jumlah dari nilai kuadrat $\mathrm{Y}$

$\left(\sum x\right)^{2}=$ jumlah nilai $\mathrm{X}$ lalu dikuadratkan

$\left(\sum y\right)^{2}=$ jumlah nilai Y lalu dikuadratkan.

Dengan kriteria pengambilan keputusan sebagai berikut:

Jika $r_{\text {hitung }}>r_{\text {tabel }}$ berarti instrumen valid, artinya data pernyataan tersebut layak digunakan.

Jika $\mathrm{r}_{\text {hitung }} \leq \mathrm{r}_{\text {tabel }}$ berarti instrumen tidak valid, artinya data pernyataan tersebut tidak layak digunakan.

Item yang punya $r$ hitung $<0,209$ akan disingkirkan akibat mereka tidak melakukan pengukuran secara sama yang dimaksud oleh skor total dan lebih jauh lagi, tidak memiliki kontribusi dengan pengukuran seseorang jika bukan malah mengacaukan.

\section{Uji Reliabilitas}

Menurut sugiyono (2016), Uji reliabilitas digunakan untuk mengukur frekuensi untuk menghasilkan data yang sama (serupa). Arikunto (2014), menyatakan bahwa: Keyakinan dalam kaitannya dengan kejelasan dapat diandalkan oleh suatu alat untuk digunakan sebagai alat pengumpulan data karena alat tersebut efisien. 


$$
r_{11}\left[\frac{k}{(k-1)}\right]\left[1-\frac{\sum \sigma_{b}^{2}}{\sigma_{t}^{2}}\right]
$$

(Arikunto, 2014)

Keterangan:

$$
\begin{array}{ll}
\mathrm{r} 11 & =\text { reliabilitas Instrumen } \\
\mathrm{k} & =\text { Banyaknya butir pernyataan } \\
\sum \sigma_{b}^{2} & =\text { jumlah varian butir pertanyaan } \\
\sigma_{t}^{2} & =\text { varians total }
\end{array}
$$

Dengan kriteria pengujian sebagai berikut:

Jika nilai cronbach's alpha $>0,60$ maka kuesioner penelitian dikatakan reliabel atau konsisten Jika nilai cronbach's alpha $<0,60$ maka kuesioner penelitian dinyatakan reliabel atau konsisten.

Untuk mempermudah mengolah data statistik yang lebih cepat dan akurat, peneliti menggunakan bantuansoftware Statistical Package for the Social Sciences (SPSS).

\subsection{Teknik Analisis Data}

Data yang dikumpulkan selanjutnya diklasifikasikan dan diorganisasikan secara sistematis serta diolah secara logis menurut rancangan penelitian yang telah ditetapkan. Pengolahan data ditujukan untuk memberi arahan argumentasi mengenai tesis yang diajukan dalam penelitian, berdasarkan data atau fakta yang diperoleh. Apabila ada hipotesis, pengolahan data diarahkan untuk membenarkan atau menolak hipotesis.

\section{Uji Normalitas}

Menurut Sugiyono (2016), Asumsi normalitas adalah mempertimbangkan residu distribusi normal. asumsi ini harus dicapai untuk model linear yang baik. Uji normalitas ini digunakan untuk menguji variabel bebas (X) dan variabel terikat (Y), dalam persamaan regresi, apakah terdistribusi atau tidak. Uji normalitas secara statistik menggunakan uji KolmogorovSmirnov. Tes ini merupakan tes sederhana yang digunakan karena lebih sederhana dan tidak menimbulkan perbedaan penglihatan. Kolmogorov-Smirnov dihitung dengan rumus Sugiyono (2016), yaitu:

$$
K S=\left[F_{r}-F_{S}\right]
$$

Dimana:

KS $\quad=$ Kolmogorov-Smirnov

$F_{r} \quad=$ Probabilitas kumulatif normal

$F_{S} \quad=$ Probabilitas Kumulatif empiris (1/data ke $\left.\mathrm{n}\right)$

Menurut Sugiyono (2016), kiteria pengambilan keputusan Kolmogorov-Smirnov adalah:

Apabila hasil perhitungan KS dengan sig. (2-tailed) < berarti distribusi sampel tidak normal.

Apabila hasil perhitungan KS dengan sig. (2-tailed) > berarti distribusi sampel normal.

Untuk mempermudah mengolah data statistik yang lebih cepat dan akurat, peneliti menggunakan bantuansoftware Statistical Package for the Social Sciences (SPSS).

\section{Uji Linearitas}

Uji linieritas digunakan untuk mengetahui apakah variabel $\mathrm{X}$ dan $\mathrm{Y}$ tersebut linier atau 
tidak, sebagai metode analisis linier atau regresi linier. Kriteria pengukuran jika $\mathrm{F}$ tabel $\mathrm{F}$ hitung, maka distribusinya satu baris, dan jika F> F tabel dihitung, maka distribusi sampelnya nol. Atau Anda dapat membandingkan nilai signifikansi (Sig), jika itu adalah Deviation from linearity Sig. > 0,05 (korelasi relatif). Tetapi jika benar sebaliknya jika Deviation from linearity Sig. <0,05 (tidak ada korelasi) antara variabel Pelayanan Prima (Service Excellence) dan Kepuasan Nasabah.

Untuk mempermudah mengolah data statistik yang lebih cepat dan akurat, peneliti menggunakan bantuansoftware Statistical Package for the Social Sciences (SPSS).

\subsection{Analisis Regresi Sederhana}

Sugiyono (2017), Analisis regresi sederhana didasarkan pada hubungan fungsional atau hubungan variabel tertentu dengan variabel dependen. Penulis menggunakan analisis regresi linier sederhana yaitu digunakan untuk mengetahui seberapa besar pengaruh variabel independen (Pelayanan Prima) terhadap variabel dependen (Kepuasan Nasabah). Persamaan umum regresi linier sederhana adalah :

$$
\mathrm{Y}=\mathrm{a}+\mathrm{bX}
$$

Dimana :

$\mathrm{Y}=$ Subyek dalam variabel dependen yang diprediksikan

$\mathrm{a}=$ Harga $\mathrm{Y}$ ketika harga $\mathrm{X}=0$ ( harga konstan)

$\mathrm{b}=$ Angka arah atau kofisien regresi, yang menunjukanangka peningkatan ataupun penurunan variabel dependen. Bila (=) arah garis naik, dan bila (-) maka arah garis turun.

$\mathrm{X}=$ Subyek pada variabel independen yang mempunyai nilai tertentu.

Nilai dapat dihitung dengan rumus :

Nilai b dapat dihitung dengan rumus :

$$
\boldsymbol{a}=\frac{\sum \mathbf{y}\left(\mathbf{x} 2-\sum \mathbf{x} \cdot \sum \mathbf{y}\right)}{\mathbf{n} \sum \mathbf{x} 2-\left(\sum \mathbf{x}\right) \mathbf{2}}
$$

$$
b=\frac{\left.\mathbf{n} \sum \mathrm{xy}-\sum \mathrm{x} \cdot \sum \mathbf{y}\right)}{\mathbf{n} \sum \mathrm{x} 2-\left(\sum \mathrm{x}\right) \mathbf{2}}
$$

Untuk mengetahui hubungan antara Pelayanan prima (Service Exellence) (X) dengan Kepuasan nasabah (Y) menggunakan Korelasi Product Moment dengan rumus:

$$
r x y=\frac{n \sum x y-\left(\sum X\right)\left(\sum Y\right)}{\sqrt{\left\{n\left(\sum x^{2}\right)-\left(\sum X\right)^{2}\right\}\left\{n\left(\sum Y^{2}\right)-\left(\sum Y\right)^{2}\right\}}}
$$

(Riduwan, 2014)

Dimana:

$\mathrm{r} \quad=$ Koefisien korelasi

$\mathrm{n} \quad=$ jumlah data

$\mathrm{X} \quad=$ Variabel Pelayanan Prima (Service Excellence)

$\mathrm{Y} \quad=$ Variabel Kepuasan Nasabah

Korelasi PPM dilambangkan (r) dengan ketentuan nilai $r$ tidak lebh dari harga $(-1 \leq \mathrm{r} \leq+$ 1). Apabila nilai $r=-1$ artinya korelasinya negatif sempurna; $r=0$ artinya tidak ada korelasi; dan $r=1$ berarti korelasinya sangat kuat. Sedangkan arti harga akan dikonsultasikan dengan 
Tabel interpretasi Nilai $r$ sebagai berikut :

Tabel 2. Interpretasi Koefisien korelasi Nilai r

\begin{tabular}{l|l}
\hline Interval Koefisien & Tingkat Hubungan \\
\hline $0,80-1,000$ & Sangat kuat \\
$0,60-0,799$ & Kuat \\
$0,40-0,599$ & Cukup Kuat \\
$0,20-0,399$ & Rendah \\
$0,00-0,199$ & Sangat Rendah \\
\hline
\end{tabular}

(Riduwan, 2014)

Untuk mengetahui besarnya kontribusi variabel X (Pelayanan Terbaik) terhadap kenaikan dan penurunan variabel Y (Kepuasan Konsumen) dapat ditentukan dengan model koefisien determinasi, dengan rumus:

$$
\mathrm{KP}=\mathrm{r} 2 \times 100 \%
$$

Dimana :

$\mathrm{KP}=$ Besarnya koefisien tertentu (determinasi)

r2 = Koefisien korelasi regresi dikuadratkan.

Untuk mempermudah mengolah data statistik yang lebih cepat dan akurat, peneliti menggunakan bantuansoftware Statistical Package for the Social Sciences (SPSS).

\subsection{Uji Hipotesis}

Pengujian hipotesis dilakukan untuk mengambil keputusan menerima atau menolak hipotesis yang diajukan. Dalam penelitian ini, untuk menguji hipotesis menggunakan uji hipotesis $\mathrm{t}$ (student test) pada tingkat keyakinan 95\% atau $\mathrm{a}=0,05 \%$ dan $\mathrm{dk}=(\mathrm{n}-2)$ dengan rumus yang dimbil menurut Riduwan sebagai berikut:

$$
\text { thitung }=\frac{\sqrt{\mathbf{n}-2}}{\sqrt{1-r^{2}}}
$$

(Riduwan, 2014)

Keterangan:

thitung $=$ Nilai $\mathrm{t}$

$\mathrm{r} \quad=$ Nilai Koefisien korelasi

$\mathrm{n} \quad=$ jumlah sampel

Adapun hipotesis penelitian ini adalah sebagai berikut:

$\mathrm{H}_{0}$ : Pelayanan Prima (Service Excellence) tidak berpengaruhsecara signifikan terhadap kepuasan Nasabah pada Unit Pengelola Kegiatan (UPK) Galuh Buana Panumbangan Ciamis.

$\mathrm{H}_{\mathrm{a}}$ : Pelayanan Prima (Service Excellence) berpengaruh secarasignifikan terhadap kepuasan Nasabah pada Unit Pengelola Kegiatan (UPK) Galuh Buana Panumbangan Ciamis.

Kriteria pengambilan keputusan ialah :

Jika $t_{\text {hitung }}>t_{\text {tabel }}$ maka $\mathrm{H} 0$ ditolak Ha diterima, artinya ada pengaruh variabel bebas $(\mathrm{X})$ terhadap variabel terikat $(\mathrm{Y})$ atau hipotesis diterima.

Jika $t_{\text {hitung }}<\mathrm{t}_{\text {tabel }}$ maka Ha ditolak dan $\mathrm{H} 0$ diterima, artinya tidak ada pengaruh variabel bebas $(\mathrm{X})$ terhadap variabel $(\mathrm{Y})$. 


\section{HASIL DAN PEMBAHASAN}

\subsection{Uji Validitas dan Uji Reliabilitas}

Uji validitas dan reliabilitas dalam penelitian ini dengan menggunakan program SPSS uji product moment pearson.

Tabel 3. Hasil Uji Validitas dan Reliabilitas

\begin{tabular}{|c|c|c|c|c|c|}
\hline Variabel & Items & $\mathrm{R}$ hitung & R tabel & $\begin{array}{c}\text { Cronbach } \\
\text { Alpha }\end{array}$ & Keterangan \\
\hline Pelayanan Prima (Service & $\mathrm{X} 1$ & 0.478 & 0.209 & 0.664 & Valid dan Reliabel \\
\hline \multirow[t]{11}{*}{ Excellence $)(\mathrm{X})$} & $\mathrm{X} 2$ & 0.469 & & & Valid dan Reliabel \\
\hline & $\mathrm{X} 3$ & 0.610 & & & Valid dan Reliabel \\
\hline & $\mathrm{X} 4$ & 0.389 & & & Valid dan Reliabel \\
\hline & $\mathrm{X} 5$ & 0.598 & & & Valid dan Reliabel \\
\hline & $\mathrm{X} 6$ & 0.408 & & & Valid dan Reliabel \\
\hline & $\mathrm{X} 7$ & 0.599 & & & Valid dan Reliabel \\
\hline & $\mathrm{X} 8$ & 0.474 & & & Valid dan Reliabel \\
\hline & $\mathrm{xg}$ & 0.273 & & & Valid dan Reliabel \\
\hline & $\mathrm{X} 10$ & 0.451 & & & Valid dan Reliabel \\
\hline & $\mathrm{X} 11$ & 0.626 & & & Valid dan Reliabel \\
\hline & $\mathrm{X} 12$ & 0.404 & & & Valid dan Reliabel \\
\hline \multirow[t]{9}{*}{ Kepuasan Nasabah (Y) } & Y1 & 0.347 & 0.209 & 0.621 & Valid dan Reliabel \\
\hline & $\mathrm{Y} 2$ & 0.347 & & & Valid dan Reliabel \\
\hline & Y3 & 0.617 & & & Valid dan Reliabel \\
\hline & Y4 & 0.587 & & & Valid dan Reliabel \\
\hline & Y5 & 0.337 & & & Valid dan Reliabel \\
\hline & Y6 & 0.481 & & & Valid dan Reliabel \\
\hline & Y7 & 0.491 & & & Valid dan Reliabel \\
\hline & Y8 & 0.597 & & & Valid dan Reliabel \\
\hline & Y9 & 0.661 & & & Valid dan Reliabel \\
\hline
\end{tabular}

(Data primer diolah, 2020)

Berdasarkan tabel 3 di atas, diketahui bahwa $t_{\text {hitung }}$ lebih besar dari $t_{\text {tabel }}$ dan nilai cronbach's alpha lebih besar dari 0,60. Kemudian dapat ditentukan bahwa nilai variabel pelayanan prima (service excellence) dan kepuasan nasabahUPK Galuh Buana dianggap valid dan dapat dipercaya.

\subsection{Uji Normalitas}

5. One-Sample Kolmogorov-Smirnov Test

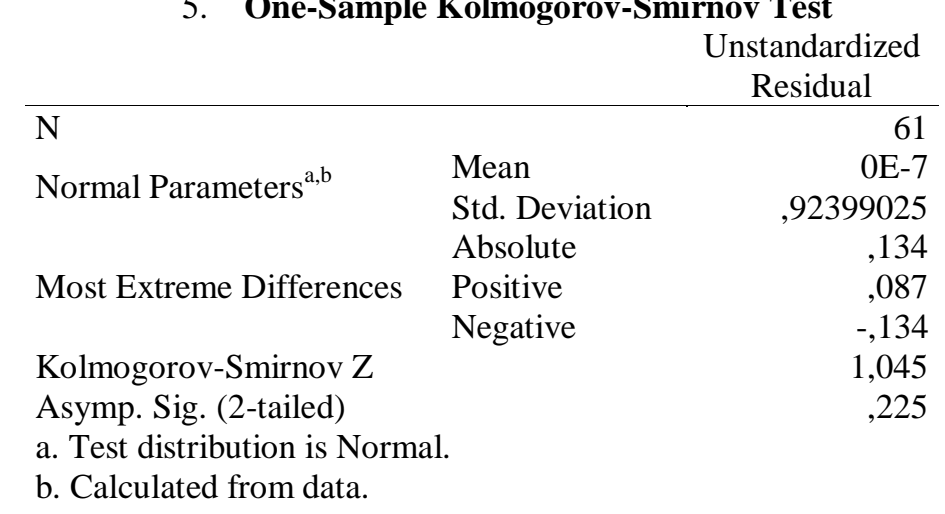

Gambar 1. Hasil Uji Normalitas

(Data diolah menggunakan SPSS v.20 for window 
Berdasarkan uji One-Sample Kolmogorov-Smirnov di atas, diketahui bahwa nilai Asymp. Sig. (2-tailed)sebesar $0.225>0.05$, sehingga dapat disimpulkan bahwa data yang diuji berdistribusi Normal.

\subsection{Uji Linearitas}

Untuk mengetahui apakah variabel Pelayanan Prima (Service Excellence) dan Kepuasan Nasabah bersifat linier, juga sebagai syarat dalam analisis korelasi dan regresi linier maka dilakukan uji linearitas. Hasil dari uji linearitas ialah sebagai berikut:

\begin{tabular}{|c|c|c|c|c|c|c|c|}
\hline & & & A Table & & & & \\
\hline & & & $\begin{array}{l}\text { Sum of } \\
\text { Squares }\end{array}$ & Df & $\begin{array}{l}\text { Mean } \\
\text { Square }\end{array}$ & $\mathrm{F}$ & Sig. \\
\hline & & (Combined) & 139,501 & 14 & 9,964 & 11,667 & ,000 \\
\hline & & Linearity & 127,561 & 1 & 127,561 & 149,360 & ,000 \\
\hline Nasabah * & Groups & Deviation & & & & & \\
\hline Pelayanan & & & 11,939 & 13 & 918 & 1,075 & ,403 \\
\hline Prima & Within C & roups & 39,286 & 46 & 854 & & \\
\hline & Total & & 178,787 & 60 & & & \\
\hline
\end{tabular}

Gambar 2. Hasil Uji Linearitas

(Data diolah menggunakan SPSS v.20 for windows)

Berdasarkan gambar di atas, diketahui bahwa nilai DfL adalah 0.403, nilai ini lebih besar dari 0.05, maka dapat disimpulkan bahwa variabel Pelayanan Prima (Service Excellence) dan Kepuasan Nasabah bersifat Linier.

\subsection{Regresi Linier Sederhana}

Untuk mengetahui pengaruh Pelayanan Prima (Service Excellence) (X) terhadap Kepuasan Nasabah (Y) dengan menggunakan analisis regresi sederhana, dengan hasil hitung sebagai berikut:

\begin{tabular}{lrrrrr}
\multicolumn{7}{c}{ ANOVA $^{\mathbf{a}}$} & & & \\
Model & Sum of Squares & Df & Mean Square & F & Sig. \\
\hline Regression & 127,561 & 1 & 127,561 & 146,921 &, $000^{\text {b }}$ \\
$1 \quad$ Residual & 51,225 & 59 &, 868 & & \\
$\quad$ Total & 178,787 & 60 & & & \\
a. Dependent Variable: Kepuasan Nasabah & & & \\
b. Predictors: (Constant), Pelayanan Prima & & &
\end{tabular}

Gambar 3. Hasil Uji analisis regresi sederhana (Data diolah menggunakan SPSS v.20 for windows

Berdasarkan gambar 3 di atas, terlihat bahwa $\mathrm{F}$ hitung $=146,921$ dengan tingkat signifikansi Probabilitas $0.000<0.05$, maka model regresi dapat dipakai untuk memprediksi variabel Kepuasan Nasabah.

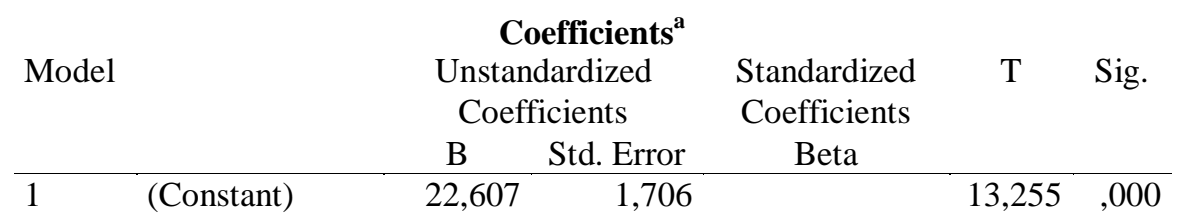




$\begin{array}{lllll}\text { Pelayanan } & \text {,398 } & , 033 & , 845 & 12,121\end{array}$

a. Dependent Variable: Kepuasan Nasabah

Gambar 4. Hasil Uji analisis regresi sederhana

(Data diolah menggunakan SPSS v.20 for windows)

Berdasarkan Gambar 4 di atas, maka dapat dinyatakan dalam persamaan jawaban regresi sederhana sebagai berikut:

$\mathrm{Y}=\mathrm{a}+\mathrm{bX}$

$\mathrm{Y}=22.607+0.398 \mathrm{X}$

Dimana:

Y: Variabel Kepusan Nasabah

a : Angka konstanta koefisien regresi

$\mathrm{b}:$ koefisien arah regresi

X: Variabel Pelayanan Prima (Service Excellence)

Dari persamaan regresi sederhana di atas, dapat dijabarkan sebagai berikut:

Nilai konstanta (a) sebesar 22.607, dan nilai koefisien arah regresinya (b) sebesar 0.398. Dapat diartikan bahwa konstanta sebesar 22,607 mengandung arti bahwa nilai konsistensi variabel kepuasan nasabah UPK Galuh Buana Panumbangan sebesar 22.607. Selanjutnya, nilai koefisien regresi X sebesar 0.355menyatakan bahwa setiap 1\% nilai Pelayanan Prima / Service Excellence (X) maka nilai Kepuasan Nasabah (Y) bertambah 0.398. Koefisien regresi baik, sehingga arah pengaruh variabel $\mathrm{X}$ ke $\mathrm{Y}$ dianggap positif.

Untuk mengetahui hubungan antara Service Excellence (X) dan Kepuasan Nasabah (Y). UPK Galuh Buana Panumbangan Ciamis ditunjukan dengan rumus korelasi Pearson Product Moment dan untuk perhitungannya menggunakan SPSS dengan hasil sebagai berikut:

\begin{tabular}{|c|c|c|c|c|}
\hline & & Model Su & $\operatorname{mary}^{b}$ & \\
\hline Model & $\mathrm{R}$ & R Square & $\begin{array}{c}\text { Adjusted R } \\
\text { Square }\end{array}$ & $\begin{array}{l}\text { Std. Error of the } \\
\text { Estimate }\end{array}$ \\
\hline 1 &, $845^{\mathrm{a}}$ & ,714 & ,709 & ,932 \\
\hline $\begin{array}{l}\text { a. Prec } \\
\text { b. Dep }\end{array}$ & $\begin{array}{l}\text { onstant } \\
\text { ariable: } \\
\text { Gan } \\
\text { ta diolal }\end{array}$ & $\begin{array}{l}\text { Pelayanan } \\
\text { epuasan } \mathrm{Na} \\
\text { ar 5. Hasil } \\
\text { menggunak }\end{array}$ & $\begin{array}{l}\text { ma } \\
\text { i koefisien kore } \\
\text { SPSS v.20 for }\end{array}$ & $\begin{array}{l}\text { lasi } \\
\text { vindows) }\end{array}$ \\
\hline
\end{tabular}

Berdasarkan gambar 5 di atas, menunjukan bahwa besarnya nilai korelasi/ hubungan (R) antara variabel Pelayanan Prima / Service Excellence (X) dan Kepuasan Nasabah (Y) UPK Galuh Buana Panumbangan Ciamis yaitu sebesar 84,5\%. Disimpulkan bahwa Interpretasi koefisien nilai $\mathrm{R}$ berada pada interval 0,80-1,000 yang berarti bahwa hubungan variabel Pelayanan Prima / Service Excellence (X) terhadap Kepuasan Nasabah (Y) UPK Galuh Buana Panumbangan Ciamis memiliki hubungan Sangat Kuat.

Tabel 4.Interpretasi Koefisien korelasi Nilai r 
๑Jajang Saeful Zaman ${ }^{1 *}$, Imas Matsny Mardiah²

$\begin{array}{cc}0,80-1,000 & \text { Sangat kuat } \\ 0,60-0,799 & \text { Kuat } \\ 0,40-0,599 & \text { Cukup Kuat } \\ 0,20-0,399 & \text { Rendah } \\ 0,00-0,199 & \text { Sangat Rendah }\end{array}$

(Riduwan, 2014)

Untuk mengetahui besarnya pengaruh Pelayanan Prima / Service Excellence (X) dan Kepuasan Nasabah (Y) UPK Galuh Buana Panumbangan Ciamis dalam penelitian ini menggunakan SPPS dengan hasil sebagai berikut:

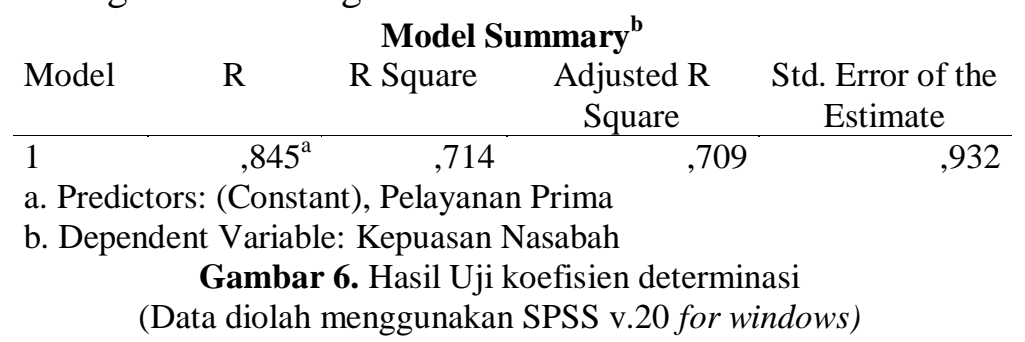

Berdasarkan gambar 6, dapat diketahui Nilai R Square sebesar 0.714 atau nilai koefisien determinasinya sebesar $71.4 \%$. Nilai ini mengandung arti bahwa pengaruh Pelayanan Prima / Service Excellence (X) terhadap Kepuasan Nasabah (Y) adalah sebesar 71.4 \% sedangkan 28.6\% Kepuasan Nasabah (Y) dipengaruhi oleh Variabel lain yang tidak diteliti dalam penelitian ini.

\subsection{Pengujian Hipotesis}

Tujuan utama penelitian ini adalah untuk mengetahui apakah Variabel Service Excellence (X) berpengaruh terhadap Kepuasan Nasabah (Y).Jika $t_{\text {hitung }}>t_{\text {tabel }}$ maka $H_{0}$ ditolak dan $\mathrm{H}_{\mathrm{a}}$ diterima, artinya ada pengaruh variabel bebas $(\mathrm{X})$ terhadap variabel terikat $(\mathrm{Y})$ atau hipotesis diterima. Sedangkan jika $\mathrm{t}_{\text {hitung }}<\mathrm{t}_{\text {tabel }}$ maka $\mathrm{H}_{\mathrm{a}}$ ditolak dan $\mathrm{H}_{0}$ diterima, artinya tidak ada pengaruh variabel bebas $(\mathrm{X})$ terhadap variabel terikat $(\mathrm{Y})$.

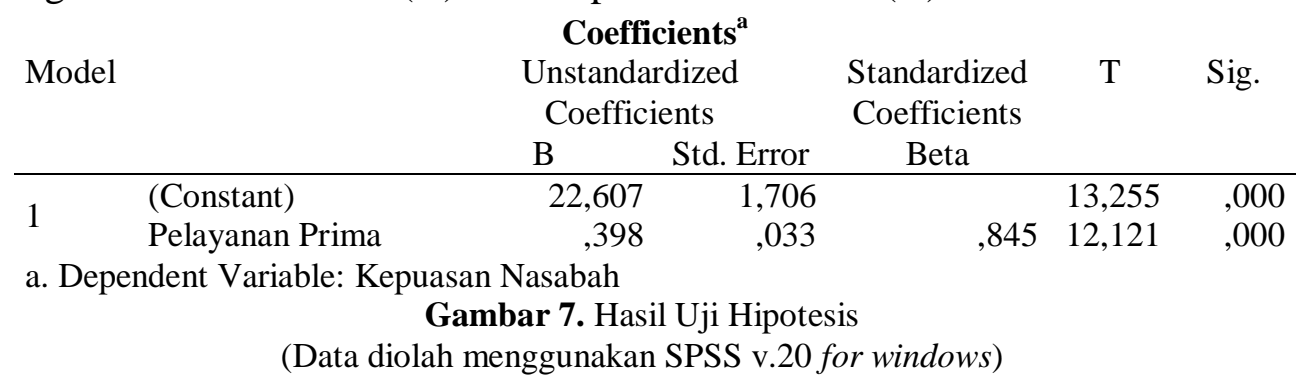

Berdasarkan gambar 7, dapat diketahui nilai $t_{\text {hitung }}$ adalah sebesar 13,255 lebih besar dari ttabel sebesar 1,671 dengan nilai signifikansi $0.000<0.05$, maka $\mathrm{H}_{\mathrm{a}}$ diterima dan $\mathrm{H}_{\mathrm{o}}$ ditolak, yang berarti ada pengaruh yang nyata (signifikan) Variabel Pelayanan Prima / Service Excellence (X) terhadap Variabel Kepuasan Nasabah (Y).

\subsection{Analisis Data Deskriptif} Pelayanan Prima (X) 
Variabel pelayanan prima memiliki 6 indikator yaitu, Kemampuan (Ability), Sikap (Attitude),Penampilan (Appearance), Perhatian (Attention), Tindakan (Action), Akuntabilitas, semua indikator diwakili oleh 5 pernyataan.

Berikut perhitungan nilai jenjang intervalnya $(\mathrm{NJI})$ :

Nilai tertinggi setiap indikator $\quad: 61 \times 5 \times 12=3.660$

Nilai Terendah setiap indikator $\quad: 61 \times 1 \times 12=732$

Jumlah kriteria pernyataan $\quad: 5$

$$
\begin{aligned}
\boldsymbol{N J I} & =\frac{\text { nilaitertinggi }- \text { nilaiterendah }}{\text { jumlahkriteriapernyataan }} \\
& =\frac{3660-732}{5} \\
& =585.6
\end{aligned}
$$

Klasifikasi penilaian untuk setiap pernyataan sebagai berikut :

Tabel 8.Kategori skala kelas interval variabel (X)

\begin{tabular}{cc} 
Kelas Interval & Kriteria \\
\hline $732-1317,6$ & Sangat Buruk \\
$1317,7-1903,1$ & Buruk \\
$1903,2-2488,7$ & Kurang Baik \\
$2448,8-3074,3$ & Baik \\
$3074,4-3660$ & Sangat Baik \\
(Data Primer diolah 2020) &
\end{tabular}

\begin{tabular}{|c|c|c|c|c|}
\hline No & Uraian & $\begin{array}{l}\text { Skor } \\
\text { tertinggi }\end{array}$ & $\begin{array}{c}\text { Skor } \\
\text { yang } \\
\text { dicapai }\end{array}$ & Kriteria \\
\hline 1. & $\begin{array}{l}\text { Petugas UPK Galuh Buana memiliki } \\
\text { pengetahuan yang memadai tentang jasa } \\
\text { yang ditawarkan kepada nasabah. }\end{array}$ & $\begin{array}{l}61 \times 5 \\
=305\end{array}$ & $272 * *$ & SB \\
\hline 2. & $\begin{array}{l}\text { Petugas UPK Galuh Buana mampu } \\
\text { menyelesaikan setiap transaksi nasabah } \\
\text { dengan cepat dan tepat. }\end{array}$ & $\begin{array}{l}61 \times 5 \\
=305\end{array}$ & 266 & SB \\
\hline 3. & $\begin{array}{l}\text { Petugas UPK Galuh Buana memiliki } \\
\text { keterampilan dalam menyampaikan } \\
\text { informasi kepada nasabah dengan bahasa } \\
\text { yang mudah dimengerti }\end{array}$ & $\begin{array}{l}61 \times 5 \\
=305\end{array}$ & 254 & B \\
\hline 4. & $\begin{array}{l}\text { Petugas UPK Galuh Buana } \\
\text { berperilaku sopan dan santun kepada } \\
\text { setiap nasabah }\end{array}$ & $\begin{array}{l}61 \times 5 \\
=305\end{array}$ & 267 & SB \\
\hline 5 & $\begin{array}{l}\text { Petugas UPK Galuh Buana selalu } \\
\text { berpenampilan rapih saat bekerja }\end{array}$ & $\begin{array}{l}61 \times 5 \\
=305\end{array}$ & 259 & SB \\
\hline 6 & $\begin{array}{l}\text { Petugas UPK Galuh Buana selalu } \\
\text { memperhatikan kebutuhan dan keinginan } \\
\text { nasabah }\end{array}$ & $\begin{array}{l}61 \times 5 \\
=305\end{array}$ & 263 & SB \\
\hline
\end{tabular}

Berikut tabel rekapitulasi variabel pelayanan prima (X)

Tabel 9.Rekapitulasi Pelayanan Prima (X) 


\begin{tabular}{|c|c|c|c|c|}
\hline 7 & Petugas UPK Galuh Buana selalu & $\begin{array}{c}61 \times 5 \\
-305\end{array}$ & 265 & SB \\
\hline 8 & $\begin{array}{l}\text { Petugas UPK Galuh Buana selalu } \\
\text { menerima kritik dan saran dari tiap } \\
\text { nasabah }\end{array}$ & $\begin{array}{l}61 \times 5 \\
=305\end{array}$ & 267 & SB \\
\hline 9 & $\begin{array}{l}\text { Petugas UPK Galuh Buana selalu } \\
\text { memberikan pelayanan yang prima kepada } \\
\text { setiap nasabah }\end{array}$ & $\begin{array}{l}61 \times 5 \\
=305\end{array}$ & 259 & SB \\
\hline 10 & $\begin{array}{l}\text { Petugas UPK Galuh Buana tidak } \\
\text { membeda-bedakan dalam melayani } \\
\text { nasabah }\end{array}$ & $\begin{array}{l}61 \times 5 \\
=305\end{array}$ & 270 & SB \\
\hline 11 & $\begin{array}{l}\text { Petugas UPK Galuh Buana memberikan } \\
\text { garansi terhadap barang yang dipesan oleh } \\
\text { nasabah }\end{array}$ & $\begin{array}{l}61 \times 5 \\
=305\end{array}$ & $253 *$ & B \\
\hline 12 & $\begin{array}{l}\text { Petugas UPK Galuh Buana memberikan } \\
\text { jaminan kerahasiaan data nasabah }\end{array}$ & $\begin{array}{l}61 \times 5 \\
=305\end{array}$ & 269 & SB \\
\hline & Jumlah Skor & 3660 & 3164 & \\
\hline
\end{tabular}

(Sumber: Data primer diolah, 2020)

*)skor terendah

**) skor tertinggi

Berdasarkan tabel 9 di atas, Mengenai hasil rekapitulasi indikator Pelayanan Prima (Service Excellence) di atas, di dapat skor total sebesar 3.164 berada pada titik 3074,4-3660 termasuk pada klasifikasi sangat baik dan memiliki skor tertinggi pada pernyataan nomor 1 yaitu Petugas UPK Galuh Buana memiliki pengetahuan yang memadai tentang jasa yang ditawarkan kepada nasabah dengan skor 272. Sedangkan nilai yang sangat rendah terdapat pernyataan nomor 11 yaitu Petugas UPK Galuh Buana memberikan garansi terhadap barang yang dipesan oleh nasabah dengan skor 253. Secara keseluruhan dapat disimpulkan bahwa Pelayanan Prima (Service Excellence) UPK Galuh Buana termasuk pada klasifikasi sangat baik.

Maka dari itu UPK Galuh Buana harus mampu mempertahankan pelaksanaan Pelayanan Prima (Service Excellence) yang sudah dinilai sangat baik oleh nasabah. Namun ada beberapa yang perlu lebih diperhatikan dan ditingkatkan lagi terkait petugas UPK Galuh Buana Panumbangan dalam memberikan garansi. Karena belum semua produk bergaransi, maka dari itu pihak UPK bisa memberikan garansi untuk semua produk. Selain itu petugas dalam menyampaikan informasi sudah dinilai baik. Namun masih sangat penting bagi UPK Galuh Buana untuk lebih meningkatkan hal tersebut dengan cara mengadakan pelatihan khusus kepada petugas UPK Galuh Buana.

Karena ketrampilan menyampaikan informasi yang jelas, cepat dan lengkap tentunya akan membantu nasabah dalam memahami informasi yang diberikan oleh petugas UPK Galuh Buana Panumbangan.Hak untuk memberikan informasi yang dibutuhkan konsumen merupakan jenis layanan yang sangat penting, karena dapat membantu konsumen mengambil keputusan yang tepat, terutama dalam situasi darurat.

\subsection{Deskripsi Jawaban Responden Variabel (Y) Kepuasan Nasabah}

Variabel Kepuasan dari 4 indikator yaitu Loyal, Mengulang kembali pembelian 
produknya, membeli lagi produk lain, memberikan promosi gratis dari mulut ke mulut, dimana semua indikator tersebut dipresentasikan oleh 5 pernyataan.

Berikut perhitungan nilai jenjang intervalnya (NJI):

Nilai tertinggi setiap indikator $\quad: 61 \times 5 \times 9=2.745$

Nilai Terendah setiap indikator $\quad: 61 \times 1 \times 9=549$

Jumlah kriteria pernataan $\quad: 5$

$$
\begin{aligned}
& \boldsymbol{N J I}=\frac{\text { nilai terting } \mathrm{i}-\text { nilai terendah }}{\text { jumlah kriteria pernyataan }} \\
= & \frac{\mathbf{2 7 4 5}-\mathbf{5 4 9}}{\mathbf{5}} \\
= & 439,2
\end{aligned}
$$

Klasifikasi penilaian untuk setiap pernyataan sebagai berikut :

Tabel 10. Kategori skala kelas interval variabel (Y)

\begin{tabular}{cc} 
Kelas Interval & Kriteria \\
\hline $549-988,2$ & Sangat Buruk \\
$988,3-1427,4$ & Buruk \\
$1.427,5-1866,6$ & Kurang Baik \\
$1.866,7-2.305,8$ & Baik \\
$2.305,9-2745$ & Sangat Baik
\end{tabular}

\begin{tabular}{|c|c|c|c|c|}
\hline No & Uraian & $\begin{array}{c}\text { Skor } \\
\text { tertinggi }\end{array}$ & $\begin{array}{l}\text { Skor } \\
\text { yang } \\
\text { dicapai }\end{array}$ & Kriteria \\
\hline 1. & $\begin{array}{l}\text { Saya selalu mengunakan jasa UPK Galuh } \\
\text { Buana sebagai layanan utama untuk } \\
\text { memenuhi kebutuhan dan keinginan saya }\end{array}$ & $61 \times 5=305$ & $303 * *$ & SB \\
\hline 2. & $\begin{array}{l}\text { Saya tidak menggunakan perusahaan jasa } \\
\text { yang lain selain UPK Galuh buana untuk } \\
\text { memenuhi kebutuhan dan keinginan saya }\end{array}$ & $61 \times 5=305$ & $303 * *$ & SB \\
\hline 3. & $\begin{array}{l}\text { Saya selalu menggunakan produk-produk } \\
\text { UPK Galuh Buana secara berulang kali }\end{array}$ & $61 \times 5=305$ & 298 & SB \\
\hline 4. & $\begin{array}{l}\text { Saya menggunakan jasa UPK Galuh Buana } \\
\text { lebih dari satu kali }\end{array}$ & $61 \times 5=305$ & 299 & SB \\
\hline 5. & $\begin{array}{l}\text { Saya selalu memberikan rekomendasi } \\
\text { pengadaaan produk-produk lain yang tidak } \\
\text { ada di UPK Galuh Buana }\end{array}$ & $61 \times 5=305$ & 294 & SB \\
\hline 6 & $\begin{array}{l}\text { Saya selalu menyarankan kepada UPK } \\
\text { Galuh Buana untuk menyediakan produk } \\
\text { lain yang dibutuhkan oleh para nasabah }\end{array}$ & $61 \times 5=305$ & 285 & SB \\
\hline 7 & $\begin{array}{l}\text { Saya selalu merekomendasikan kepada } \\
\text { masyarakat sekitar untuk menggunakan jasa } \\
\text { UPK Galuh Buana }\end{array}$ & $61 \times 5=305$ & 292 & SB \\
\hline
\end{tabular}

Berikut Rekapitulasi dari variabel (Y) Kepuasan Nasabah:

Tabel 11. Rekapitulasi Kepuasan Nasabah(Y) 
8 Saya selalu membicarakan Pelayanan Prima yang dilakukan oleh UPK Galuh Buana kepada masyarakat sekitar

9 Saya selalu membujuk masyarakat sekitar untuk mau menggunakan jasa UPK Galuh

$61 \times 5=305$

291

$61 X 5=305 \quad 272 *$

SB Buana

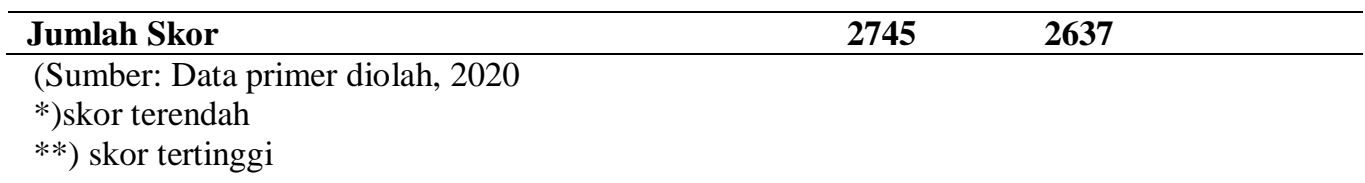

Berdasarkan tabel 11, Mengenai hasil rekapitulasi indikator Kepuasan Nasabah di atas, di dapat skor total sebesar 2.637 berada pada titik 2.305,9- 2745 termasuk pada klasifikasi sangat baik dan memiliki skor tertinggi pada pernyataan nomor 1 yaitu Nasabah selalu mengunakan jasa UPK Galuh Buana sebagai layanan utama untuk memenuhi kebutuhan dan keinginannya dengan skor 303, dan pernyataan nomor 2 yaitu Nasabah tidak menggunakan perusahaan jasa yang lain selain UPK Galuh buana untuk memenuhi kebutuhan dan keinginannya dengan skor 303 . Sedangkan nilai yang sangat rendah terdapat pernyataan nomor 9 yaitu Nasabah selalu membujuk masyarakat sekitar untuk mau menggunakan jasa UPK Galuh Buana dengan skor 272. Secara keseluruhan dapat disimpulkan bahwa Kepuasan Nasabah UPK Galuh Buana termasuk pada klasifikasi sangat baik. Adapun Nasabah yang menilai tidak puas bukan karena pelayanan prima yang diberikan UPK yang belum maksimal namun pada ketua kelompok SPKP yang kurang maksimal kepada anggotanya sehingga hasilnya penilaian terhadap UPK Galuh Buana sangat baik.

\section{KESIMPULAN}

Berdasarkan hasil penelitian dan pembahasan di atas dapat disimpulkan:

a. Berdasarkan hasil indeks Pelayanan Prima (X) UPK Galuh Buana, skor total sebesar 3.164 yang berkisar 3074,4-3660 secara umum merupakan kriteria sangat baik. Sehingga dapat disimpulkan secara luas bahwa pelayanan terbaik (Service Excellence) menurut responden dalam klasifikasi adalah yang terbaik.

b. Berdasarkan hasil Indeks Kepuasan Konsumen UPK Galuh Buana, sebanyak 2.637 skor yang diberikan antara 2.305,9-2745 yang artinya kriteria sangat baik. Oleh karena itu ditetapkan baik bagi nasabah jika klasifikasi responden sangat baik. Bagi nasabah yang merasa kurang puas bukan karena pelayanan UPK yang baik, tetapi karena ketua kelompok SPKP kurang baik terhadap anggotanya.

c. Berdasarkan hasil survey terdapat pengaruh kualitas pelayanan terhadap kesejahteraan pelanggan UPK Galuh Buana Panumbangan. Hasil koefisien kumulatif sebesar 0,845 menunjukkan interpretasi nilai koefisien $\mathrm{R}$ berada pada kisaran 0,80-1,000 yang menunjukkan bahwa korelasi tersebut sangat kuat. Keberlanjutan penyelesaian sebesar 71,4\% sedangkan 28,6\% kepuasan Konsumen (Y) dipengaruhi oleh variabel lain yang tidak diteliti dalam penelitian ini. Penelitian ini sejalan dengan penelitian sebelumnya, namun terdapat perbedaan efektivitas pelayanan yang baik untuk kepentingan 
pelanggan, penelitian Handini 99,2016\%, penelitian Rizki 41,5\% dan survei Immanuel $43,7 \%$.

\section{SARAN}

Agar UPK Galuh Buana Panumbangan semakin meningkatkan Kepuasan nasabah khususnya pelayanan yang prima maka dapat dilakukan hal-hal sebagai berikut:

a. UPK Galuh Buana perlu melakukan pembenahan dalam hal penyediaan garansi barang, karena tidak semua bergaransi. Oleh karena itu, sebaiknya UPK Galuh Buana Panumbangan dapat memberikan garansi untuk semua barang / produk.

b. Peneliti menghimbau UPK Galuh Buana untuk meningkatkan keterampilan petugas menyampaikan informasi kepada pelanggan dalam bahasa yang mudah dipahami, dengan mengadakan pelatihan khusus bagi petugas UPK. Hal ini perlu diperhatikan karena keakuratan distribusi informasi yang dibutuhkan oleh pemasar akan memperbaiki pikiran konsumen, menjadi jelas dan positif, serta membantu konsumen dalam mengambil keputusan yang tepat, terutama dalam situasi yang mengejutkan.

c. Untuk peneliti selanjutnya yang ingin meneliti UPK Galuh Buana Panumbangan, mereka bisa memeriksa topik ini. Penelitian selanjutnya diharapkan dapat memperluas populasi survei, menambah variabel spesifik untuk mengetahui variabel lain yang mempengaruhi variabel Dependen (KepuasanNasabah) maupun dengan meneliti variabel lain di UPK Galuh Buana Panumbangan.

\section{REFERENSI}

Antoni, M. S. (2018). Pengaruh kualitas pelayanan prima (service excellence), porsi bagi hasil dan tingkat pendapatan nasabah terhadap tabungan firdaus pada PT. Bank Aceh Syariah Langsa. Jurisprudensi: Jurnal Ilmu Syariah, Perundang-Undangan, Ekonomi Islam, 10(1), 34-61. https://doi.org/10.32505/jurisprudensi.v10i1.870

Arikunto, Suharsimi. (2014). Prosedur Penelitian Suatu Pendekatan Praktik.Rhineka Cipta.

Dwi Divayana, K. A., \& Rahanatha, G. B. (2018). Studi komparatif pengaruh kualitas pelayanan terhadap kepuasan nasabah pada PT. BPR. Mertha Sedana dan PT. BPR. Mas Giri Wangi. E-Jurnal Manajemen Universitas Udayana, 7(4), 2134. https://doi.org/10.24843/ejmunud.2018.v07.i04.p15

Kotler, P., \& Keller, K. L. (2016). Marketing Management (15 th). Pearson Education, Inc.

Kriswahyu. (2009). Standar pelayanan publik sesuai UU no 25 tahun 2009. Ombudsman Republik Indonesia.

Rangkuty, F. (2017). Customer care excellence meningkatkan kinerja perusahaan melalui pelayanan prima. PT Gramedia Pustaka Utama.

Sebayang, I. E. S. (2019). Pengaruh service excellence terhadap kepuasan nasabah PT. bank SUMUT kantor cabang pembantu USU. Jurnal Ilmiah Skylandsea, 3, 299-307. 
๑Jajang Saeful Zaman ${ }^{1 *}$, Imas Matsny Mardiah²

https://www.google.com/search?client=firefox-b-

$\mathrm{d} \& \mathrm{q}=$ PengaruhService+ExcellenceTerhadap+Kepuasan+Nasabah+PTBank+Sumut+Kant or+Cabang+Pembantu+Usu

Sunyoto, D. (2015). Perilaku konsumen dan pemasaran. CAPS.

Sudjana. (2005). Metode Statistika Edisi ke-6. Bandung: Tarsito.

Sugiyono. (2016). Metode Penelitian Manajemen Kuantitatif, Kualitatif dan R\&D. Alfabeta.

Sugiyono. (2017). Metode Penelitian Kuantitatif, Kualitatif dan R\&D. Alfabeta.

Sujarweni, V Wiratna. (2015). Statistik untuk Bisnis \& Ekonomi. Pustaka Baru Press.

Tjiptono, F. (2014). Pemasaran jasa. CV. Andi Offset. 